\title{
Pengaruh Model Pembelajaran Problem Posing Berbantuan Media Semi Konkret terhadap Kompetensi Pengetahuan Matematika
}

\author{
*Ni Md. Arianti ${ }^{1}$ I Wyn. Wiarta ${ }^{2}$, I Wyn. Darsana ${ }^{3}$
}

1,2,3Jurusan Pendidikan Dasar, Universitas Pendidikan Ganesha, Singaraja, Indonesia

\author{
A R T I C L E I N F O \\ Article history: \\ Received 15 August 2019 \\ Received in revised form \\ 20 September 2019 \\ Accepted 10 October 2019 \\ Available online 27 \\ November 2019

\section{Kata Kunci: \\ Problem Posing, Semi \\ Konkret, Matematika \\ Keywords: \\ Semi-Concrete Problem} \\ Posing, Mathematics
}

\begin{abstract}
A B S T R A K
Banyak faktor yang menyebabkan rendahnya kompetensi pengetahuan matematika di dalam dunia pendidikan yaitu proses pembelajaran masih dilakukan secara klasikal atau kelompok besar. Penggunaan model pembelajaran yang tidak bervariasi menyebabkan siswa merasa bosan dan tidak bersemangat dalam mengikuti pembelajaran. Oleh karena matematika merupakan pembelajaran yang sangat penting, sehingga dibutuhkan suatu model yang dapat membantu siswa meningkatkan kompetensi pengetahuan matematika. Penilitian ini bertujuan untuk mengetahui perbedaan yang signifikan kompetensi pengetahuan matematika antara kelompok yang dibelajarkan melalui model pembelajaran problem posing berbantuan media semi konkret dengan kelompok siswa yang dibelajarkan melalui pembelajaran konvensional pada siswa kelas V SD. Jenis penelitian yang digunakan yaitu eksperimen semu dengan desain nonequivalent control group design. Populasi penelitian meliputi seluruh kelas V SD pada semester genap
\end{abstract} sebanyak 643 siswa. Sampel penelitian ditentukan dengan teknik simple random sampling. Sampel dalam penelitian ini adalah kelas V A SD sebanyak 49 siswa sebagai kelompok eksperimen dan kelas V A SD sebanyak 44 siswa sebagai kelompok kontrol. Metode pengumpulan data dalam penelitian ini adalah metode tes pilihan ganda biasa. Berdasarkan hasil analisis data, diperoleh thitung $=3,005$ dan tabel pada taraf signifikansi $5 \%,(\alpha=2,000$. Hal ini berarti thitung $>$ tabel sehingga dapat diinterprestasikan bahwa terdapat perbedaan yang signifikan kompotensi pengetahuan matematika antara kelompok siswa yang dibelajarkan melalui model pembelajaran problem posing berbantuan media semi konkret dengan kelompok siswa yang dibelajarkan melalui pembelajaran konvensional. Dengan demikian dapat disimpulkan bahwa model pembelajaran problem posing berbantuan media semi konkret berpengaruh terhadap kompetensi pengetahuan matematika siswa kelas V SD.

\begin{abstract}
A B S T R A C T
Many factors cause the low competence of mathematical knowledge in the world of education. The use of learning models that did not vary causes students to feel bored and unenthusiastic in learning. Mathematics was very important learning, so we needed a model that could help students to improve their mathematics knowledge competence. This research aimed to determine the significant difference in mathematics knowledge competence between groups who were taught through problem posing learning models assisted by semi-concrete media with groups of students who were taught through conventional on fifth grade students. The type of research used was a quasi-experimental design with nonequivalent control group design. The research population included all the fifth grade totalled 643 students. The research sample was determined by simple random sampling. The sample was class $V$ A elementary students totalled 49 students as the experimental group and class VA elementary school totalled 44 students as a control group. The method of data collection in this research was multiple choice test. Based on the results obtained t-count $=3,005$ and $t$-table at a significance level of $5 \%$, $(\alpha=2,000$. This meant $t$-count $>t$-table so that could be interpreted that there was a significant difference in mathematics knowledge competence between groups of students who were taught through assisted problem posing learning models semi-concrete media with groups of students learned through conventional learning It could be concluded that the problem posing learning model
\end{abstract}

Copyright (C) Universitas Pendidikan Ganesha. All rights reserved. 
assisted by semi-concrete media had an effect on the mathematics knowledge competence on fifth grade students.

\section{Pendahuluan}

Pendidikan merupakan salah satu pilar yang sangat penting dalam menghasilkan sumber daya manusia yang berkualitas. Melalui pendidikan, seseorang akan mampu mengembangkan segala pengetahuan dan potensi yang dimilikinya. Lebih dari itu, seseorang dengan pendidikan yang berkualitas akan mampu menciptakan suatu kreativitas dan inovasi yang sesuai dengan bidangnya, sehingga dapat mengangkat harkat dan martabat dirinya, keluarga, lingkungan, bahkan bangsa dan negaranya. (Sanjaya, 2010)

Undang-undang Sistem Pendidikan Nasional No. 20 Tahun 2003 menyatakan bahwa pendidikan nasional bertujuan untuk mengembangkan potensi peserta didik agar menjadi manusia yang beriman dan bertakwa kepada Tuhan Yang Maha Esa, berakhlak mulia, sehat, berilmu, cakap, kreatif, mandiri dan menjadi warga negara yang demokratis serta bertanggung jawab. Hal tersebut berarti bahwa pendidikan harus menjadi skala prioritas yang utama agar manusia mempunyai arah dan tujuan yang jelas mengenai apa yang akan dikerjakan dan dipilih untuk memenuhi kebutuhan hidupnya. Salah satu yang ditempuh oleh pemerintah untuk meningkatkan kualitas pendidikan yaitu penyempurnaan kurikulum tingkat satuan pendidikan (KTSP) menjadi kurikulum tahun 2013.

Susanto (2015:185) menyatakan bahwa, "Matematika merupakan salah satu disiplin ilmu yang dapat meningkatkan kemampuan berpikir dan berargumentasi, memberikan kontribusi dalam penyelesaian masalah sehari-hari dan dalam dunia kerja, serta memberikan dukungan dalam pengembangan ilmu pengetahuan dan teknologi". Kebutuhan akan aplikasi matematika saat ini dan masa depan tidak hanya untuk keperluan sehari-hari, tetapi terutama dalam dunia kerja, dan untuk mendukung perkembangan ilmu pengetahuan. Oleh karena itu, matematika sebagai ilmu dasar perlu dikuasai dengan baik oleh siswa, terutama sejak usia sekolah dasar. Menurut (Elda Efriani, Lusi Eka Afri, n.d.)Pembelajaran Matematika adalah suatu proses interaksi antara guru dengan siswa dalam suatu bentuk aktifitas yang terorganisir memperoleh informasi, mampu memahami dan memiliki kemampuan untuk mengkomunikasikan kembali informasi yang diperoleh sebelumnya. Interaksi atau hubungan timbal balik antara guru dan siswa merupakan cara utama untuk kelangsungan proses pembelajaran matematika. Salah satu indikasi seseorang telah melewati proses pembelajaran yaitu adanya perubahan tingkah laku pada diri orang tersebut yang mungkin disebabkan oleh terjadinya perubahan pada aspekaspek tertentu. Perubahan-perubahan yang terjadi pada diri seseorang setelah belajar itulah yang disebut sebagai hasil belajar.

Kompetensi merupakan perpaduan skill, tingkah laku dan pengetahuan serta nilai-nilai dasar yang dapat didemonstrasikan atau direfleksikan dalam kebiasaan dan kemampuan berpikir dan bertindak peserta didik sebagai yang dicapai melalui kegiatan mengajar yang bermakna dan penuh arti (Yusuf, 2015). Matematika adalah pola berpikir, pola mengorganisasikan, pembuktian yang logis, matematika itu adalah bahasa yang menggunakan istilah yang didefinisikan dengan cermat, jelas dan akurat representasinya dengan simbol dan padat, lebih berupa bahasa simbol mengenai ide (gagasan) dari pada mengenai bunyi ((Supriyanto et al., 2014)). Matematika adalah pengetahuan struktur yang terorganisasi, sifat-sifat dalam teori-teori dibuat secara deduktif berdasarkan kepada unsur yang tidak didefinisikan, aksioma, sifat atau teori yang telah dibuktikan kebenarannya adalah ilmu tentang keteraturan pola atau ide, dan matematika itu adalah suatu seni, keindahannya terdapat pada keterurutan dan keharmonisannya. Dalam pembelajaran di kelas guru cenderung menerapkan metode teacher centre atau berpusat pada guru. Selain itu pembelajaran matematika seringkali dianggap sebagai mata pelajaran yang sulit dimengerti oleh sebagian besar peserta didik, sehingga membuat prestasi belajar matematika peserta didik terhadap mata pelajaran matematika tidak sesuai yang diharapkan.

Keberhasilan proses pembelajaran merupakan hal utama yang didambakan dalam melaksanakan pendidikan di sekolah. Mencapai kemampuan yang diharapkan dalam pembelajaran matematika, diperlukan perubahan dalam berbagai komponen pendidikan, seperti halnya dalam strategi pembelajaran yang digunakan. Hal ini disebabkan karena banyaknya anggapan pada peserta didik, bahwa matematika merupakan sesuatu hal yang sulit, sehingga matematika tidak disukai dalam pembelajaran, yang pada akhirnya prestasi dalam pembelajaran tidak sesuai dengan yang diharapkan. Oleh karena itu, diperlukan suatu startegi pembelajaran matematika yang harus berorientasi pada peserta didik, yang menekankan pada kemampuan berpikir kritis pada peserta didik. Salah satu strategi pembelajaran yang dapat mengembangkan kemampuan berpikir kritis bagi peserta didik adalah dengan menerapkan pembelajaran Problem Posing berbantuan media semi konkret. Pembelajaran Problem Posing berbantuan media semi 
konkret menekankan pada perumusan soal yang dapat mengembangkan kemampuan berpikir kritis dan komunikasi matematis peserta didik.

Banyak faktor yang menyebabkan rendahnya kompetensi pengetahuan matematika yaitu di dalam dunia pendidikan proses pembelajaran masih dilakukan secara klasikal atau kelompok besar. Penggunaan model pembelajaran yang tidak bervariasi sehingga menyebabkan siswa merasa bosan dan tidak bersemangat dalam mengikuti pembelajaran. Pembelajaran matematika yang sangat penting diberikan kepada siswa tapi sayang anggapan dari siswa sangat sulit dan menakutkan. Hal ini dapat diperkuat oleh observasi yang telah dilaksanakan di SD Gugus Kapten Kompyang Sujana. Pada tanggal 14 Desember 2018 dengan guru kelas V (lima) di masing-masing SD Gugus Kapten Kompyang Sujana, diperoleh bahwa nilai kompetensi pengetahuan matematika siswa kelas $\mathrm{V}$ (lima) sebagian besar masih berada di bawah nilai Kriteria Ketuntasan Minimal (KKM). Dimana KKM untuk kompetensi pengetahuan matematika yang diharapkan dalam kurikulum 2013 adalah 70,00. Dari 643 jumlah siswa kelas V yang berada di Gugus Kapten Kompyang Sujana, 14 siswa mendapat nilai (A), 14 siswa mendapat nilai (A-), 56 siswa mendapat nilai (B+), 66 siswa mendapat nilai (B), 53 siswa mendapat nilai (B-), 73 siswa mendapat nilai (C+), 80 siswa mendapat nilai (C), 172 siswa mendapat nilai (C-), 51 siswa mendapt nilai (D+), 64 siswa mendapat nilai (D). Dari 643 jumlah siswa kelas V sebanyak 203 siswa sudah mencapai KKM sedangkan 68\% dari siswa 440 siswa yang belum mencapai KKM. Hal ini mengindikasikan bahwa ketuntasan belajar pada muatan materi Matematika di SD Gugus Kapten Kompyang Sujana tersebut belum terpenuhi dan perlu mendapat penanganan yang serius Melihat kondisi seperti itu, perlu kiranya melakukan pengembangan dan peningkatan mutu dalam pembelajaran matematika, yakni pembelajaran yang mampu mengoptimalkan interaksi setiap elemen untuk menumbuh kembangkan kemampuan berpikir.

Problem Posing merupakan model pembelajaran yang mengharuskan siswa menyusun pertanyaan sendiri atau memecah suatu soal menjadi pertanyaan-pertanyaan yang lebih sederhana (I Putu Arie Indra Permana1, Prof. Dr. Nyoman Dantes2, 2017). Diharapkan pembelajaran dengan model Problem Posing dapat meningkatkan motivasi siswa untuk belajar sehingga pembelajaran yang aktif akan tercipta, siswa tidak akan bosan dan lebih tanggap. Dengan begitu akan mempengaruhi hasil belajarnya dan akan menjadi lebih baik (Aris, 2014). Penerapan Problem Posing berbantuan media semi konkret, diharapkan pembelajaran mampu menjadi efektif dan efesien. Dengan demikian, perlu diketahui pengaruh pembelajaran Problem Posing berbantuan media semi konkret terhadap kompotensi pengetahuan matematika peserta didik. Model pembelajaran ini di bantu dengan media semi konkret karena pada tahap semi konkret sudah tidak perlu memanipulasi objek-objek konkret, tetapi cukup dengan gambaran dari objek yang dimaksud. Dengan menggunakan media semi konkret ini dapat lebih mudah untuk memecahkan suatu permasalahan di dalam proses pembelajaran matematika. Berdasarkan beberapa penjelasan tersebut terlihat bahwa strategi pembelajaran Problem Posing berbantuan media semi konkret dapat dijadikan sebagai salah satu upaya untuk menjadikan pembelajaran di kelas lebih efektif dan mencapai tujuan pembelajaran dan model ini memiliki kelebihan sebagai berikut mendidik siswa berpikir kritis dan siswa aktif dalam pelajaran, serta memiliki kekurangan sebagai berikut memerlukan waktu yang cukup banyak dan tidak bisa digunakan di kelas rendah. (Yulisma, 2017) Model pembelajaran problem posing merupakan suatu pembelajaran yang melibatkan siswa secara aktif, siswa berusaha untuk mengembangkan pengetahuannya yang sesuai dengan tiori konstruktivistik. Guru hanya berperan sebagai fasilitator. Siswa belajar secara kolaboratif, dimana akan terjadi interaksi dua arah yang aktif. Penerapan model pembelajaran problem posing membiasakan siswa berperan aktif untuk dapat mengembangkan pengetahuannya melalui pengajuan pertanyaan dan juga menjawab pertanyaan dari temannya dalam kelompok lain. (Rustina, 2016) Problem posing merupakan aktivitas yang mengharuskan peserta didik untuk menyusun pertanyaan-pertanyaan dari suatu situasi kemudian menyelesaikannya baik secara individu maupun secara berkelompok.

(Aris, 2014) Menyatakan bahwa langkah-langkah Model Pembelajaran Problem Posing sebagai berikut. (1) Guru menjelaskan materi pelajaran kepada para siswa. Penggunaan alat peraga untuk memperjelas konsep sangat disarankan. (2) Guru memberikan latihan soal secukupnya. (3) Siswa diminta mengajukan 1 atau 2 buah soal yang menantang, dan siswa yang bersangkutan harus mampu menyelesaikannya. Tugas ini dapat pula dilakukan secara kelompok. (4) Pada pertemuan berikutnya, secara acak, guru menyuruh siswa untuk menyajikan soal temuannya di depan kelas. Dalam hal ini, guru dapat menentukan siswa secara selektif berdasarkan bobot soal yang diajukan oleh siswa. (5) Guru memberikan tugas rumah secara individual. Menurut (Aris, 2014) kelebihan dari model pembelajaran Problem Posing sebagai berikut. (1) Mendidik murid berpikir kritis. (2) Siswa aktif dalam pelajaran. (3) Perbedaan pendapat antara siswa dapat diketahui sehingga mudah diarahkan pada diskusi yang sehat. (4) Belajar menganalisis suatu masalah. (5) Mendidik anak percaya diri sendiri. Menurut (Aris, 2014)kekurangan dari model pembelajaran Problem Posing sebagai berikut (1) Memerlukan waktu yang cukup banyak, (2) Tidak bisa digunakan di kelas rendah, (3) Tidak semua anak didik terampil bertanya. 
Berdasarkan paparan di atas dapat dirangkum model pembelajaran Problem Posing merupakan model pembelajaran yang mengharuskan siswa menyusun pertanyaan sendiri atau memecah suatu soal menjadi pertanyaan-pertanyaan yang lebih sederhana. Yang memiliki kelebihan sebagai berikut mendidik murid berpikir kritis dan siswa aktif dalam pelajaran, serta memiliki kekurangan sebagai berikut memerlukan waktu yang cukup banyak tidak bisa digunakan di kelas rendah.

Berdasarkan uraian di atas, maka di pandang perlu untuk melaksanakan penelitia yang berjudul "Pengaruh Model Pembelajaran Problem Posing Berbantuan Media Konkret Terhadap Kompetensi Pengetahuan Matematika Siswa Kelas V SD Gugus Kapten Kompyang Sujana Denpasar Barat Tahun 2018/2019."

\section{Metode}

Penelitian ini dilaksanakan di kelas V SD Gugus Kapten Kompyang Sujana Tahun Ajaran 2018/2019. Yang dilaksanakan pada bulan April 2019 sampai bulan Mei 2019, di dua sekolah dasar di Gugus Kapten Kompyang Sujana. Sampel dalam penelitian ini yaitu SD Negeri 8 Padangsambian sebagai kelompok eksperimen dan SD Negeri 2 Padangsambian sebagai kelompok kontrol, terdiri atas pemberian pretest, pemberian perlakuan sebanyak 6 kali dan pemberian posttest pada kelompok eksperimen dan kelompok kontrol.

Rancangan penelitian yang digunakan dalam penelitian ini adalah penelitian kuantitatif dengan desain eksperimen semu (quasi experimental design). Bentuk desain eksperimen semu yang digunakan adalah Nonequivalent Control Group Design (Sugiyono, 2017). Dalam desain ini terdapat dua kelompok, yaitu kelompok eksperimen dan kelompok kontrol. Desain tersebut dapat diformulasikan dengan gambar 1 sebagai berikut.

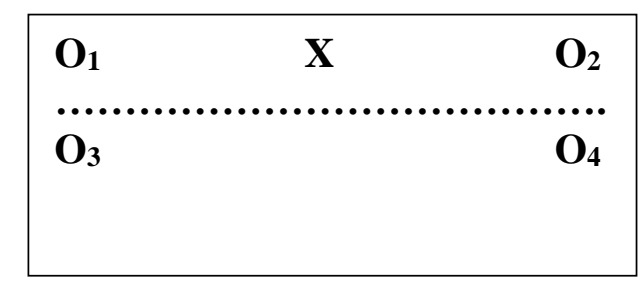

Keterangan :

Gambar 1.

Rancangan Penelitian Nonequivalent Control Group Design

$\mathrm{O}_{1}=$ Pretest pada kelompok eksperimen

$\mathrm{O}_{2}=$ Posttest pada kelompok eksperimen

$\mathrm{O}_{3}=$ Pretest pada kelompok kontrol

$\mathrm{O}_{4}=$ Posttest pada kelompok kontrol

$\mathrm{X}=$ Perlakuan dengan model pembelajaran Problem Posing Berbantuan Media Semi Konkret

Penelitian ini dilakukan dengan menempuh langkah-langkah yang terdiri dari tiga tahapan yaitu: tahap persiapan, tahap pelaksanaan, dan tahap akhir eksperimen. Adapun uraian dari setiap tahapan yaitu pada tahap persiapan, hal yang dilakukan adalah melakukan wawancara dengan kepala gugus, menyusun RPP beserta LKS, mengkonsultasikan instrumen penelitian bersama wali kelas dan dosen pembimbing, mengadakan uji coba instrumen, melakukan pengundian untuk menentukan kelompok eksperimen dan kelompok kontrol, memberikan pretest, serta menguji kesetaraan data pretest dengan uji t. Kemudian pada tahap pelaksanaan hal yang dilakukan adalah memberikan perlakuan pada kelas eksperimen berupa model pembelajaran Problem Posing berbantuan media semi konkret sebanyak enam kali dan memberikan posttest, serta memberikan perlakuan pada kelas kontrol berupa pembelajaran konvensional sebanyak enam kali dan memberikan posttest. Pada tahap akhir eksperimen hal yang dilakukan adalah menganalisis data hasil penelitian dan melakukan uji hipotesis. Dalam suatu penelitian untuk menentukan subjek penelitian, langkah awal yang dilakukan adalah menentukan populasi yang akan diteliti. (Agung, 2014) Menyatakan bahwa populasi adalah keseluruhan objek dalam suatu penelitian. Sedangkan menurut (Sugiyono, 2017) populasi adalah wilayah generalisasi yang terdiri atas: obyek/subyek yang mempunyai kualitas dan karakteristik tertentu yang ditetapkan oleh peneliti untuk mempelajari dan kemudian ditarik kesimpulannya.

Berdasarkan paparan kedua para ahli diatas dapat disimpulkan populasi adalah keseluruhan objek penelitian, kumpulan subjek, variabel, konsep, atau fenomena yang memenuhi syarat-syarat tertentu 
sesuai dengan masalah penelitian yang telah diteliti untuk kemudian ditarik kesimpulan. Populasi dalam penelitian ini adalah seluruh siswa kelas V SD Gugus Kapten Kompyang Sujana Denpasar Barat. Setelah menentukan populasi maka selanjutnya menentukan sampel penelitian. Sampel merupakan salah satu unsur dari pupulasi yang hendak dijdikan suatu objek penelitian. (Agung, 2014) Menyatakan bahwa sempel ialah sebagian dari populasi yang diambil, yang dianggap mewakili seluruh populasi. (Sugiyono, 2017) Sempel adalah bagian dari jumlah dan karakteristik yang dimiliki oleh populsi tesebut. Berdasarkan pendapat dua ahli diatas maka peneliti menyimpulkan sampel adalah bagian dari populasi yang dijadikan subyek penelitian sebagai wakil dari pada anggota populasi.

Teknik sampling adalah merupakan teknik pengambilan sanpel (Sugiyono, 2017). Teknik pengambilan ini menggunakan randam sampling yang dirandom kelasnya sehingga setiap kelas mendapat peluang yang sama untuk menjadi sampel didalam sebuah penelitian. Pemilihan sempel penelitian ini tidak dilakukan pengacakan individu melainkan pengacakan kelas. Karena tidak bisa mengubah kelas yang telah terbentuk sebelumnya. Dikatakan simple (sederhana) karena pengambilan sampel dari populasi dilakukan secara acak tanpa memperhatikan strata yang ada dalam populasi itu (Sugiyono, 2017). Teknik ini dengan cara mencampur subyek didalam populasi sehingga semua subyek dianggap sama, semu subyek mendapat yang sama untuk memperoleh kesempatan dipilih menjadi anggota sampel. Teknik sampel random dapat dilakukan dengan cara: undian, ordinal dan bilangan random (Agung, 2014). Sebelum menentukan sampel, seluruh kelas dalam populasi haruslah setara, maka dari itu seluruh kelas dalam populasi diberikan pretes. Skor yang diperoleh dari pretes digunakan untuk melakukan uji kesetaraan sampel menggunakan uji-t. Jika keadaan sampel sudah setara, maka akan dilanjutkan dengan menentukan kelas dengan cara diundi. Dalam penelitian ini sampel yang dipilih adalah dua kelas, yaitu satu kelas eksperimen dan satu kelas kontrol. Kedua kelas tersebut nantinya akan diberikan perlakukan yang berbeda. Satu kelas akan diberikan perlakuan dengan model pembelajaran Problem Posing dan satu kelas lagi diberikan perlakuan menggunakan pembelajaran Sampel dalam penelitian ini adalah kelas V A SD Negeri 8 Padangsambian sebagai kelompok eksperimen dan kelas V A SD Negeri 2 Padangsambian sebagai kelompok kontrol.

Instrumen penelitian adalah suatu alat yang digunakan mengukur fenomena alam maupun sosial yang diamati (Sugiyono, 2017). Dalam penelitian ini, instrumen yang digunakan untuk mengukur kemampuan kompetensi pengetahuan matematika adalah test. (Agung, 2014) Menyatakan bahwa metode tes dalam kaitannya dengan penelitian ialah cara memperoleh data yang berbentuk suatu tugas yang dilakukan atau dikerjakan oleh seorang atau sekelompok orang yang dites (testee), dan dari tes tersebut dapat menghasilkan suatu data berupa skor (data interval). Metode tes digunakan untuk mengukur kemampuan individu siswa. Serta peningkatan nilai siswa sebelum dan sesudah mendapatkan perlakuan pada kelas eksperimen. Test digunakan pada akhir siklus yang digunakn untuk menunjukkan kompetensi pengetahuan yang dicapai pada setiap siklus, yang bertujuan untuk mengetahui apakah ada peningkatan kompetensi pengetahuan matematika peseta didik setelah menerapkan pembelajaran dengan menggunakan model pelajaran Problem Posing.

Dalam penelitian ini terdapat dua variabel, yaitu variabel bebas dan variabel terikat. (Sugiyono, 2017) variabel bebas merupakan variabel yang mempengaruhi atau yang menjadi sebab perubahannya atau timbulnya variabel dependem (terikat). Sedangkan menurut (Agung, 2014) variabel bebas yaitu satu atau lebih dari variabel-variabel yang sengaja dipelajari pengaruhnya terhadap variabel tergantung. Jadi berdasarkan paparan kedua para ahli diatas mempengaruhi atau yang menyebabkan terjadinya perubahan. Variabel bebas dalam penelitian ini adalah model pembelajaran Problem Posing berbantuan media semi konkret $(x)$. (Sugiyono, 2017) Menyatakan bahwa varabel terikat merupakan variabel yang dipengaruhi atau menjadi akibat, karena adanya variabel bebas. Sedangkan (Agung, 2014) variabel terantung variabel-variabel yang keberadannya munculnya bergantung pada variabel bebas. Jadi berdasarkan paparan kedua para ahli diatas dapat disimpulkan variabel terikat adalah faktor-faktor yang diamati dan diukur oleh peneliti dalam sebuah penelitian, untuk menentukan ada tidaknya pengaruh dari variabel bebas. Variabel terikat dalam penelitian ini adalah Kompetensi Pengetahuan Matematika $(y)$

Data yang dikumpulkan dalam penelitian ini adalah data kompetensi pengetahuan matematika siswa kelas V SD Gugus Kapten Kompyang Sujana. Data dikumpulkan dengan menggunakan metode tes. Metode tes adalah cara memperoleh data berbentuk tugas yang diberikan dan harus dikerjakan oleh seseorang atau kelompok yang di tes (Agung, 2014).Tes yang digunakan dalam penelitian ini berupa tes objektif dalam bentuk pilihan ganda biasa. Tes objektif dengan bentuk pilihan ganda biasa disusun berdasarkan indikator-indikator muatan materi matematika yang dimuat dalam kisi-kisi, dengan empat pilihan jawaban, yaitu a. b, c, d. Sebelum tes diberikan kepada kelompok eksperimen dan kelompok kontrol terlebih dahulu dilakukan uji instrumen. Pengujian terhadap instrumen penelitian digunakan untuk mendapatkan gambaran secara empirik apakah instrumen layak digunakan sebagai instrumen penelitian. Setelah dilakukan uji coba instrumen selanjutnya dilakukan uji validitas, uji daya beda, indeks 
kesukaran, dan uji reliabilitas untuk mendapatkan instrumen yang baik. Uji validitas adalah untuk mengukur validitas butir test kompetensi pengetahuan matematika dalam pilihan ganda (objektif) digunakan rumus koenfisien korelasi point biserial $\left(\mathrm{r}_{\mathrm{pbi}}\right)$ karena bersifat dikotomi. Uji daya beda adalah pengukuran sejauh mana suatu butir soal maupun membedakan peseta didik yang sudah menguasai kompetensi dengan peserta didik yang belum/kurang menguasai kompetensi berdasarkan kriteria tertentu. Indeks Kesukaran dapat dipandang sebagai kesanggupan atau kemampuan siswa menjawab tes yang diberikan, seangan uji reliabilitas dilakukan terhadap hasil pengukuran atau pengamatan bila fakta atau kenyataan hidup tadi diukur atau diamati berkali-kali dalam waktu yang berlainan, dengan demikian uji reliabilitas bisa dilakukan setelah dilakukan uji validitas. Dari hasil uji instrumen terhadap 37 siswa, didapatkan 30 butir instrumen yang layak dipergunakan dari total keseluruhan instrumen yaitu 40 butir.

Dalam penelitian ini data yang terkumpul akan dianalisis menggunakan metode analisis statistik deskriptif dan metode analisis statistik inferensial. Data yang dianalisis berupa data gain skor yang ternormalisasikan dari hasil pretest dan posttest. Statistik deskriptif digunakan untuk menganalisis data kompetensi pengetahuan matematika pada kelompok eksperimen dan kelompok kontrol, statistik deskriptif yang dipergunakan yaitu, mean, standar deviasi, varians. Statistik inferensial adalah statistik inferensial, (sering juga disebut statistik induktif atau statistik probabilitas), adalah teknik statistik yang digunakan untuk menganalisis data sampel dan hasilnya diberlakukan untuk populasi" (Sugiyono, 2017). Teknik analisis data yang dilakukan adalah uji hipotesis menggunakan uji $t$, sebelum dilakukan uji hipotesis, terlebih dahulu dilakukan uji prasyarat analisis data berupa uji normalitas sebaran data dan uji homogenitas varians, apabila data berdistribusi normal dan homogen maka dilanjutkan dengan analisis statistik parametrik dengan teknik uji t dengan rumus polled varians, Dengan kriteria pengujian jika harga $t_{\text {hitung }} \leq t_{\text {tabel, }}$ maka $\mathrm{H}_{\mathrm{o}}$ diterima, dan jika harga $\mathrm{t}_{\text {hitung }}>\mathrm{t}_{\text {tabel }}$ maka $\mathrm{H}_{\mathrm{o}}$ ditolak. Pada taraf signifikan $5 \%$ dengan $\mathrm{dk}=\mathrm{n}_{1}+\mathrm{n}_{2}-2$.

\section{Hasil dan Pembahasan}

Penelitian ini merupakan penelitian yang berbentuk quasi experiment atau eksperimen semu yang menggunakan rancangan nonequivalent control group design yang dianalisis menggunakan uji t. Objek dalam penelitian ini adalah kompetensi pengetahuan matematika kelas V SD Negeri Gugus Kapten Kompyang Sujana Denpasar Barat Tahun Ajaran 2018/2019. Yang dibelajarkan melalui model pembelajaran dengan model pembelajaran Problem Posing berbantuan media semi konkret. dan yang dibelajarkan dengan pembelajaran konvensional.

Pada awal penelitian kelompok eksperimen dan kelompok kontrol diberikan pretest, setelah diberikan pretest kelompok eksperimen dibelajarkan dengan model pembelajaran Problem Posing berbantuan media semi konkret dan kelompok kontrol dibelajarkan melalui pembelajaran konvensional sebanyak 6 kali, dan pada akhir penelitian kelompok eksperimen dan kelompok kontrol diberikan posttest, hasil pretest dan posttest dari kedua kelompok kemudian diolah menjadi data gain skor ternormalisasi. Berdasarkan hasil gain skor ternormalisasi diperoleh rata-rata kelompok eksperimen adalah 0,26 lebih besar dari kelompok kontrol yaitu 0,15. Kemudian rata-rata gain skor ternormalisasi kompetensi pengetahuan matematika pada kelompok eksperimen dan kelompok kontrol dikonversikan pada tabel pengkategorian PAN skala lima. Setelah dikonversikan pada pengkategorian PAN skala lima, rata-rata kompetensi pengetahuan matematika kelompok eksperimen berada pada kategori Cukup Baik dan kelompok kontrol berada pada kategori Cukup Baik.

Berdasarkan data gain skor ternormalisasi kompetensi pengetahuan matematika, yang berdistribusi normal dan varians yang homogen, diperoleh hasil uji t dengan harga $t_{\text {hitung }}=3,005$, harga ini kemudian dibandingkan dengan harga tabel pada taraf signifikansi $5 \%(\alpha=0,05)$ dengan dk $(49+44-2=$ 91), sehingga diperoleh harga $t_{\text {tabel }}=2,000$. Oleh karena harga $t_{\text {hitung }}=3,005>$ harga $t_{\text {tabel }}=2,000$, maka $\mathrm{H}_{0}$ ditolak. Berikut disajikan rekapitulasi hasil analisis data dengan menggunakan uji t pada Tabel 1

Tabel 1. Rekapitulasi Analisis Uji t

\begin{tabular}{clcccccc}
\hline No & \multicolumn{1}{c}{ Sampel } & $\mathbf{N}$ & $\overline{\mathbf{X}}$ & $\mathbf{S}^{\mathbf{2}}$ & $\mathbf{t}_{\text {hitung }}$ & $\mathbf{t}_{\text {tabel }}$ & Simpulan \\
\hline 1 & Kelompok Eksperimen & 49 & 0,26 & 0,0340 & \multirow{2}{*}{3,005} & \multirow{2}{*}{2,000} & \multirow{2}{*}{$\mathrm{H}_{0}$ ditolak } \\
2 & Kelompok Kontrol & 44 & 0,15 & 0,0281 & & & \\
\hline
\end{tabular}

Hal ini berarti terdapat perbedaan yang signifikan kompetensi pengetahuan matematika antara kelompok siswa yang dibelajarkan melalui model pembelajaran Problem Posing berbantuan media semi konkret dengan kelompok siswa yang dibelajarkan melalui pembelajaran konvensional pada siswa kelas $\mathrm{V}$ SD Gugus Kapten Kompyang Sujana Tahun Ajaran 2018/2019. Dengan demikian model pembelajaran, 
Problem Posing berbantuan media semi konkret berpengaruh terhadap kompetensi pengetahuan matematika siswa kelas V SD Gugus Kapten Kompyang Sujana Tahun Ajaran 2018/2019.

Berdasarkan perolehan nilai kompetensi pengetahuan matematika siswa pada kedua kelompok, dapat diketahui bahwa kedua kelompok yang awalnya memiliki kemampuan yang setara. Setelah diberikan perlakuan pada kelompok eksperimen, perolehan nilai kompetensi pengetahuan matematika mengalami perbedaan. Kompetensi pengetahuan matematika siswa pada kelompok eksperimen lebih baik apabila dibandingkan dengan kompetensi pengetahuan matematika pada kelompok kontrol. Perbedaan hasil kompetensi pengetahuan matematika pada kelompok eksperimen dan kelompok kontrol disebabkan oleh perlakuan berupa model pembelajaran Problem Posing berbantuan media semi konkret yang diberikan kepada kelompok eksperimen.

Pada kegiatan pembelajaran di kelompok eksperimen menggunakan model pembelajaran Problem Posing berbantuan media semi konkret berjalan secara optimal dan kondusif. Hal ini disebabkan model pembelajaran Problem Posing berbantuan media semi konkret merupakan model pembelajaran yang membuat siswa lebih termotivasi, karena dengan penggunaan kelompok dalam belajar yang terdiri dari 45 orang, yang tentunya kelompok ini bersifat heterogen. Dipastikan heterogen karena adanya tes penempatan dalam pembentukan setiap kelompok, memiliki perbedaan individual siswa secara akademik dalam menyelesaikan tugas untuk mencapai tujuan bersama dan kompetensi matematika yang maksimal. Hal ini menuntut siswa secara aktif untuk menemukan informasi dan membangun pengetahuannya sendiri dengan memberi permasalahan yang diselesaikan secara berkelompok serta saling menghargai pendapat sehingga terciptanya solidaritas sosial yang kuat di kalangan siswa (Pratiwi, 2017). Selain itu pemberian skor dan penghargaan (recognition) kepada tim atau kelompok yang memenuhi kriteria sebagai "tim super", juga akan menumbuhkan motivasi dan minat setiap siswa untuk lebih tekun dan bersemangat mengalahkan kelompok lain dalam menyelesaikan suatu permasalahan yang diberikan, sehingga proses pembelajaran akan menjadi lebih aktif dan terciptanya rasa senang dalam belajar matematika. Didalam proses pembelajaran dengan menggunakan model Problem Posing dibantu dengan adanya media semi konkret, adanya media semi konkret membuat siswa lebih aktif dalam kegiatan pembelajaran dan meningkatkan kreativitas serta kemampuan berpikir kritis siswa dalam penyelesaian masalah.

Pembelajaran dengan menggunakan model pembelajaran Problem Posing berbantuan media semi konkret khususnya pada muatan materi matematika bab penyajian data tunggal memberikan kesempatan yang lebih luas kepada siswa untuk mengkontruksikan pengetahuannya dengan penyelesaian masalah bersama kelompok, masalah yang diberikan berdasarkan pemahaman dan kehendaknya, yang membuat keaktifan, kreatifitas dan kemampuan berpikir kritis siswa meningkat.

(Aris, 2014) Langkah-langkah Model Pembelajaran Problem Posing sebagai berikut. (1) Guru menjelaskan materi pelajaran kepada para siswa. Penggunaan alat peraga untuk memperjelas konsep sangat disarankan. (2) Guru memberikan latihan soal secukupnya. (3) Siswa diminta mengajukan 1 atau 2 buah soal yang menantang, dan siswa yang bersangkutan harus mampu menyelesaikannya. Tugas ini dapat pula dilakukan secara kelompok. (4) Pada pertemuan berikutnya, secara acak, guru menyuruh siswa untuk menyajikan soal temuannya di depan kelas. Dalam hal ini, guru dapat menentukan siswa secara selektif berdasarkan bobot soal yang diajukan oleh siswa. (5) Guru memberikan tugas rumah secara individual. (Martiani, 2016) Kelebihan dari model pembelajaran Problem Posing sebagai berikut. (1) Mendidik murid berpikir kritis. (2) Siswa aktif dalam pelajaran. (3) Perbedaan pendapat antara siswa dapat diketahui sehingga mudah diarahkan pada diskusi yang sehat. (4) Belajar menganalisis suatu masalah. (5) Mendidik anak percaya diri sendiri. Menurut Aris Shoimin (2014:135) kekurangan dari model pembelajaran Problem Posing sebagai berikut (1) Memerlukan waktu yang cukup banyak, (2) Tidak bisa digunakan di kelas rendah, (3) Tidak semua anak didik terampil bertanya.

Berdasarkan paparan di atas dapat dirangkum model pembelajaran Problem Posing merupakan model pembelajaran yang mengharuskan siswa menyusun pertanyaan sendiri atau memecah suatu soal menjadi pertanyaan-pertanyaan yang lebih sederhana (Hasibuan, 2016). Kelebihan dari model ini yaitu mendidik murid berpikir kritis dan siswa aktif dalam pelajaran, serta memiliki kekurangan memerlukan waktu yang cukup banyak tidak bisa digunakan di kelas rendah.

Hasil temuan penelitian pada penelitian ini memiliki persamaan dengan penelitian yang relevan sebelumnya dan memperkuat hasil penelitian yang diperoleh. Hal ini didukung oleh hasil penelitian oleh Ike Rasmianti (2013) menunjukkan bahwa terdapat perbedaan yang signifikan anatar kemampuan pemecahan masalah matematika siswa yang mengikuti pembelajaran dengan metode pembelajaran Problem Posing berpengaruh terhadap pemecahan masalah matematika siswa kelas IV SD Gugus VI Kecamatan Banjar tahun pelajaran 2012/2013. Begitupula dengan hasil penelitian (I Putu Arie Indra Permana1, Prof. Dr. Nyoman Dantes2, 2017)bahwa penerapan model pembelajaran Problem Posing 
berpengaruh terhadap hasil belajar IPS siswa kelas V SD Gugus IV Kerinci Kecamatan Melaya Tahun Ajaran 2016/2017.

\section{Simpulan dan Saran}

Berdasarkan penelitian yang telah dilakukan maka dapat ditarik simpulan sebagai berikut. Berdasarkan analisis data kompetensi pengetahuan matematika pada kelompok eksperimen yang dibelajarkan dengan model Pembelajara Problem Posing Berbantuan Media Semi Konkret diperoleh ratarata gain skor, $\bar{X}=0,26$ dengan nilai gain skor tertinggi 0,80 dan nilai gain skor yang terendah 0,08 . Ratarata gain skor kompetensi pengetahuan matematika tersebut kemudian dikonversikan pada PAN skala lima, sehingga dapat diketahui kompetensi pengetahuan matematika siswa kelompok eksperimen berada pada kategori Cukup Baik.

Berdasarkan analisis data kompetensi pengetahuan matematika pada kelompok kontrol yang dibelajarkan melalui pembelajaran konvensional diperoleh skor rata-rata gain skor, $\bar{X}=0,15$ dengan nilai gain skor tertinggi 0,40 dan nilai gain skor terendah 0,07. Rata-rata gain skor kompetensi pengetahuan matematika tersebut kemudian dikonversikan pada tabel PAN skala lima, sehingga dapat diketahui kompetensi pengetahuan matematika siswa kelompok kontrol pada kategori Cukup Baik.

Terdapat perbedaan yang signifikan kompetensi pengetahuan matematika antara kelompok siswa yang dibelajarkan melalui model pembelajaran Problem Posing Berbantuan Media Semi Konkret dengan yang dibelajarkan melalui Pembelajaran Konvensional siswa kelas V SD Gugus Kapten Kompyang Sujana Tahun Ajaran 2018/2019. Hal ini terbukti dari Hasil analisis uji-t diperoleh thitung $=3,005$. Harga tersebut kemudian dibandingkan dengan harga tabel dengan $\mathrm{dk}=91$ dan taraf signifikansi $5 \% \quad(\alpha=0,05$ sehingga diperoleh $t_{\text {tabel }}=2,000$ karena $t_{\text {hitung }}=3,005>t_{\text {tabel }}=2,000$ maka $\mathrm{H}_{0}$ diterima. Hal ini berarti terdapat perbedaan yang signifikan kompetensi pengetahuan matematika kelompok siswa yang dibelajarkan melalui model pembelajaran Problem Posing Berbantuan Media Semi Konkret dan kelompok siswa yang dibelajarkan melalui pembelajaran konvensional pada kelas V SD Gugus Kapten Kompyang Sujana Tahun Ajaran 2018/2019. Rata-rata kompetensi pengetahuan matematika siswa kelompok eksperimen $\bar{X}_{1}=0,26$ $>\bar{X}_{2}=0,15$ rata-rata kompetensi pengetahuan matematika kelompok kontrol, sehingga dapat disimpulkan bahwa model pembelajaran Problem Posing Berbantuan Media Semi Konkret berpengaruh terhadap kompetensi pengetahuan matematika siswa kelas V SD Gugus Kapten Kompyang Sujana Tahun Ajaran 2018/2019.

Berdasarkan hasil penelitian, pembahasan dan simpulan, maka dapat diajukan beberapa saran kepada beberapa pihak sebagai berikut. (1) kepada guru, Penelitian ini agar bisa dijadikan acuan untuk meningkatkan keterampilan dalam merancang pembelajaran dengan tujuan memperoleh hasil belajar yang optimal. Guru yang mengajar menggunakan tematik disarankan untuk mengembangkan inovasi pembelajaran dengan menerapkan strategi, pendekatan, model, metode, dan media yang mampu mengoptimalkan hasil belajar siswa. (2) Kepada kepala sekolah, Kepala sekolah diharapkan memberikan sosialisasi secara berkelanjutan mengenai inovasi-inovasi pembelajaran kepada guru dalam membelajarkan siswa agar dapat mengoptimalkan hasil belajar siswa sehingga mutu sekolah menjadi semakin meningkat. (3) Peneliti lain, Kepada peneliti lainnya, bahwa dalam penelitian ini terbatas pada pokok materi Penyajian Data Tunggal siswa kelas V. Untuk memperoleh kompetensi yang berbeda dan pada muatan materi yang berbeda peneliti menyarankan kepada peneliti lain supaya melakukan penelitian pada pokok bahasan materi yang lebih beragam untuk memperoleh hasil yang lebih baik.

\section{Daftar Rujukan}

Agung, A. A. G. (2014). Metodologi Penelitian Pendidikan. Aditya: Media Publish.

Aris, S. (2014). Model pembelajaran Inovatif Dalam Kurikulum 2013. In 1 (Issue). Yogyakarta: AR-ruz media.

Elda Efriani, Lusi Eka Afri, A. (n.d.). Pengaruh Penerapan Model Pembelajaran Problrm Posing Terhadap Hasil Belajar Siswa. Jurnal Mhasiswa FKIP Universitas Pasir Pengraian, 1(1), 1-5.

Hasibuan, Elmisari. 2016. Pengaruh Model Pembelajaran Problem Posing Terhadap Hasil Belajar Kognitif Fisika Siswa Kelas VII MTs PP Raudatussalam Rambah Pada Konsep Besaran dan Satuan. Jurnal Ilmiah Mahasiswa FKIP Prodi FISIKA, Vol. 1(1).

I Putu Arie Indra Permana1, Prof. Dr. Nyoman Dantes2, D. D. P. P. (2017). Pengaruh Model Pembelajaran 
Kuantum Terhadap Hasil Belajar Ips Siswa Kelas V. MIMBAR PGSD Undiksha, 5(2). https://doi.org/10.23887/jjpgsd.v5i2.10910

Martiani, Eulis \& Wida Rachmiati. 2016. Penerapan Model Problem Posing Untuk Meningkatkan Hasil Belajar Matematika Tentang Operasi Hitung Campuran. Jurnal Ibtida'i, Vol. 3(02);(157-168)

Pratiwi, Trishna Ayudya. 2017. Pengaruh Model Pembelajaran Cooperative Tsts Berbantuan Peta Konsep Terhadap Kompetensi Pengetahuan IPA Siswa Kelas V. e-Journal PGSD Universitas Pendidikan Ganesha Mimbar PGSD, Vol. 5(2).

Rasmianti, Ike, dkk. 2013. Pengaruh Metode Pembelajaran Problem Posing Terhadap Kemampuan Pemecahan Masalah Matematika Siswa Kelas IV SD Gugus Vi Kecamatan Banjar. e-Jurnal Universitas Pendidikan Ganesha Mimbar PGSD, Vol. 1(1).

Rustina, R. (2016). Efektifitas Penggunaan Model Pembelajaran Problem Posing terhadap Peningkatan kemampuan Berpikir Kritis Mahasiswa. Penelitian Pendidikan Dan Pengajaran Matematika, 2(Maret), 41-48.

Sanjaya, W. (2010). Strategi Pembelajaran Berorientasi Standar Proses Pendidikan. In 1. Prenada Media Group.

Sugiyono. (2017). Statistiak untuk Penelitian. Alfabeta.

Supriyanto, A., Mardiyana, \& Subanti, S. (2014). Karakteristik Berpikir Matematis Siswa SMP Majelis Tafsir Al- Qur' an ( MTA ) Gemolong dalam Memecahkan Masalah Matematika pada Materi Sistem Persamaan Linear Dua Variabel ( Spldv ) Ditinjau dari Kemampuan Penalaran Siswa dan Gender. Jurnal Elektronik Pembelajaran Matematika, 2(10), 1056-1068.

Yulisma. (2017). Model Pembelajaran Problem Posing Untuk Meningkatkan Hasil Belajar Bahasa Indonesia Siswa Sekolah Menengah Pertama. Jurnal Ilmu Pendidikan Sosial, Sains, Dan Humaniora, 3(1), 99-108. https://doi.org/http://dx.doi.org/10.24014/suara\%20guru.v3i1.3052

Yusuf, M. (2015). Asesmen Dan Evaluasi Pendidikan Pilar Penyedia Informasi dan Kegiatan Pengendalian Mutu Pendidikan. In 1. Prenadamedia Group. 